\title{
Ontogeny of Adenohypophyseal Cells, Pituitary Gland Development and Structure in Adults of Astyanax Lacustris (Teleostei, Characidae): an Emerging Neotropical Fish Species
}

Giovana Souza Branco ( $\sim$ giovana_branco@hotmail.com )

Universidade de Sao Paulo https://orcid.org/0000-0002-4481-2436

Lázaro Wender O. De Jesus

Universidade Federal de Alagoas

Monica Cassel

Universidade Federal do Triangulo Mineiro

Chayrra Chehade

Universidade de Sao Paulo

Marília de Paiva Camargo

Universidade de Sao Paulo

Gisele C. M. Dias

Universidade de Sao Paulo

Maria Ines Borella

Universidade de Sao Paulo

\section{Research Article}

Keywords: Characiformes, Adenohypophysis, Early development, Histochemistry, Immunocytochemistry

Posted Date: December 16th, 2021

DOI: https://doi.org/10.21203/rs.3.rs-1119779/v1

License: (c) (1) This work is licensed under a Creative Commons Attribution 4.0 International License.

Read Full License 


\section{Abstract}

Pituitary gland morphogenesis of the adenohypophyseal $(\mathrm{AH})$ cells of Astyanax lacustris are presented herein. This Characiformes species show great ecological and commercial importance, and it has been increasingly used as a biological model. The first AH cells of $A$. lacustris were detected at 1 dah by the immunostaining of PRL producing cells. The morphology of the gland presented changes in shape throughout the development, starting elongated but more oval at the end. The neurohypophysis was differentiated at 3 dah, along with the identification of ACTH, MSH, TSH, and FSH producing cells. Identification of the immunoreactive cells to anti-LH, anti-SL, and anti-GH antibodies occurred at 5 dah. At 20 dah, an increase in pituitary size and the presence of the pituitary stalk were observed. At 60 dah, the pituitary already had the same shape seen in adults. The ontogeny of adenohypophyseal cells in $A$. lacustris corroborates the heterogeneity in the appearance of these cell types in teleosts and suggests that these hormones actively participate during the early development of this species. Our results collaborate with the understanding of the morphogenesis of the hypothalamic-pituitary-gonadal axis in South American teleosts, showing essential data for the development of future studies related to pituitary morphophysiology.

\section{Introduction}

The pituitary gland is considered the "master gland" of vertebrates (Schreibman 1986) since the hormones produced by its several adenohypophyseal $(\mathrm{AH})$ cells play a crucial role on the neuroendocrine control of all endocrine axes. So, this gland is involved in the early development, growth, reproduction, metabolism adaptation to the environment, as well as to stress responses (Kawauchi and Sower 2006).

In teleost, peptides produced by the hypothalamic nuclei are transported by amyelinic fibers through the neurohypophysis $(\mathrm{NH})$ branches to be released adjacent to the AH cells, since fish do not have a hypophyseal portal system (Yaron and Levavi-Sivan 2011). The different types of endocrine cells are found isolated or in small groups located in specific regions of the pituitary gland. The hormones secreted by AH cells reach the bloodstream and can interact with their cognate receptors in endocrine glands or in different tissues distributed throughout the body. This interaction triggers the production of other hormones or signaling molecules, culminating with their specific biological responses (Agulleiro et al. 2006). Based on their structural and functional similarities, the $A H$ hormones can be grouped in three families: (1) the growth hormone (GH), prolactin (PRL) and somatolactin (SL) family; (2) the glycoprotein hormone family, composed by the thyroid stimulating hormone (TSH), and the two gonadotropic hormones (GTHs) - the follicle stimulating hormone (FSH) and the luteinizing hormone (LH); and (3) the proopiomelanocortin family, with the adrenocorticotropic hormone (ACTH) and melanotropic hormone (MSH) (Kawauchi and Sower 2006).

Many developmental studies have pointed to the species-specific variations in the emergence of the different populations of $\mathrm{AH}$ cells, corroborating the structural diversity of the pituitary gland seen in adult fish (Agulleiro et al. 2006; Schreibman 1986). Since the early development of the embryonic period is 
variable between different species and groups, this may result in a heterochrony in the activation of the endocrine axis (Agulleiro et al. 2006; Laiz-Carrión et al. 2003). Despite the importance of these studies, and considering the great diversity and relevance in aquaculture, only few studies have been done on Neotropical fish species, as Odontesthes bonariensis (Atheriniformes; Miranda et al. 2001), Salminus brasiliensis (Characiformes; Jesus et al. 2014), and Cichlasoma dimerus (Perciformes; Pandolfi et al. 2001, 2003).

The yellow tail tetra Astyanax lacustris (Chaciformes, Characidae) is a South American species widely used in fish farming and human consumption. Due its small size, easy handling, early sexual maturation, sexual dimorphism, and multiple spawning, this species has been pointed out as an emerging Neotropical fish model species. An increasing number of data has been accumulated about its biology, regarding its early development (Adolfi et al. 2015; Dos Santos et al. 2016), gametogenesis (Camargo et al. 2017; Cassel et al. 2017; Chehade et al. 2015; Costa et al. 2014; De Jesus et al. 2017; Rodrigues et al. 2017), reproductive physiology (Brambila-Souza et al. 2019; Branco et al. 2019; De Jesus et al. 2017), as well its use in biotechnological applications (Adamov et al. 2017; Ferreira do Nascimento et al. 2017; Yasui et al. 2015) and as bioindicator in ecotoxicological studies (Cimbaluk et al. 2018; Kida et al. 2016).

In this study we used Astyanax lacustris as a model species to analyze the pituitary gland development, the ontogeny of $\mathrm{AH}$ cells, and its topographic organization in adults. Our results provide, then, the basis for further studies related to the endocrine axis mediated by the pituitary gland in this Neotropical species.

\section{Material And Methods}

\section{Animals and sampling}

A. lacustris specimens were donated by the Hydrobiology and Aquaculture Station of Votorantim Energia Group, company formerly called CESP, Paraibuna, São Paulo, Brazil ( $\left.23^{\circ} 24^{\prime} 51^{\prime \prime} \mathrm{S}, 4^{\circ} 35^{\prime} 59^{\prime \prime} \mathrm{W}\right)$. Fertilized eggs were obtained from a reproductive management, as described by Chehade et al. (2015) and Cassel et al. (2017). Time zero (0) was considered when at least $70 \%$ of the eggs hatched, which occurred after 18.5 hours of incubation. From this time, larvae were sampled at $0.5,1,1.5,2,2.5,3,4,5,8$, and 12 days after hatching (dah). The juveniles were sampled at 20,30,60,90 dah, and adults at 120 dah $(n=20$ in each sample).

All specimens were euthanized by benzocaine overdose. Larvae until 12 dah had the whole body fixed; late larvae, juveniles, and adults had only their head fixed, after jaw extraction and brain exposition. All samples were fixed by immersion in Bouin's solution for 24 hours at room temperature. All experimental procedures were performed according to the procedure approved by the Ethics Committee on Animal Experiments of the Institute of Biomedical Sciences (ICB) of the University of Sao Paulo (USP), \#53/2013.

\section{Histological and histochemical preparations}


After fixation, samples were washed in running water to remove the excess of fixative solution. Head fragments were decalcified in RDO Gold (Apex) according to the instructions of the manufacturer. Then,

all samples were dehydrated in increasing concentrations of ethanol, diaphanized in xylene, and embedded in Paraplast. To further use in histochemical and immunohistochemical analyzes, serial $5 \mu \mathrm{m}$ sections were obtained and placed on poly-L-lysine-coated slides.

For histochemistry, some sections were deparaffinized in xylene, rehydrated in ethanol series, and stained with Mallory trichrome. All sections were dehydrated, mounted, and analyzed using an Olympus BX51 light microscope coupled with a digital QColor5 camera (Olympus) and equipped with Image Pro-Plus digital image capture software.

\section{Immunohistochemistry}

After a previous selection, the sections with the pituitary gland were deparaffinized in xylene and rehydrated in ethanol series and phosphate-buffered saline (PBS, pH 7.4). Endogenous peroxidase and non-specific binding sites blockages were performed using the solutions from the Kit Spring Reveal Polyvalent Free Biotin-DAB (SPD-125). Sections were then incubated overnight in a humid chamber at $4^{\circ} \mathrm{C}$ using different polyclonal primary antibodies diluted in PBS. The primary antibodies and the dilutions used herein are detailed in Table 1.

Table 1

Primary antibodies used in the immunohistochemistry reactions

\begin{tabular}{|c|c|c|c|}
\hline Antibody & Source & Code & Dilution \\
\hline Anti-salmon PRL ${ }^{a, \star}$ & Dr. H. Kawauchi & 8206 & $1: 5000$ \\
\hline Anti-salmon $\mathrm{GH}^{\mathrm{a}, \star}$ & Dr. H. Kawauchi & 8502 & $1: 200$ \\
\hline Anti-salmon $\mathrm{SL}^{\mathrm{a}, *}$ & Dr. H. Kawauchi & 8906 & 1:1000 \\
\hline Anti-human $\mathrm{ACTH}_{1-24}{ }^{\mathrm{a}_{1} *}$ & Dako & - & 1:1000 \\
\hline Anti-human $\beta$-TSH ${ }^{a,+}$ & Dr. A.F. Parlow & 55741789 & $1: 100$ \\
\hline Anti-A. lacustris Fshb a,\# & - & $630158-1$ & $1: 1500$ \\
\hline Anti-A. lacustris Lhb ${ }^{\mathrm{b}, \#}$ & - & $630159-1$ & $1: 20$ \\
\hline \multicolumn{4}{|c|}{ Host species: ${ }^{a}$ Antibody produced in rabbit; ${ }^{b}$ Antibody produced in rat. } \\
\hline \multicolumn{4}{|c|}{ Antibodies previously standardized in *\# De Jesus et al. (2017) and ${ }^{+}$Nozaki et al. (2005) } \\
\hline
\end{tabular}


After that, sections were washed in PBS and incubated with the Complement and Conjugated solutions from the same Kit Spring Reveal, according to the instructions of the manufacturer. Sections were rewashed in PBS, revealed with 3,3'-diaminobenzidine (DAB), and counterstained with Harrys hematoxylin. Finally, slides were mounted, analyzed, and photo documented, as already described. The primary antibodies were omitted in some sections as negative control. The specificity of each antibody may also be verified in previous studies, in which all these antibodies have already been characterized (Table 1).

\section{Results}

All the AH cells were detected in Astyanax lacustris during the first days after hatching, as shown in Table 2. In general, the different cell populations were found presenting a few cells during their first appearance. We are not able to detect the pituitary anlage (Fig. 1A). However, at 1 dah we observed a small group of cells strongly immunostained by the anti-PRL antibody, the PRL cells, which are shown as small cells with a large, central nucleus (Fig. 1B).

Table 2

Chronology of the appearance of AH cells in Astyanax lacustris during the larval period

\begin{tabular}{|llllllllll|}
\hline \multirow{2}{*}{ Time } & \multicolumn{2}{l}{ AH cells } & & & & & & \\
\cline { 2 - 8 } & PRL & ACTH & MSH & TSH & FSH & LH & SL & GH \\
\hline Hatching & - & - & - & - & - & - & - & - \\
\hline 0.5 dah & - & - & - & - & - & - & - & - \\
\hline 1 dah & + & - & - & - & - & - & - & - \\
\hline 1.5 dah & + & - & - & - & - & - & - & - \\
\hline 2 dah & + & - & - & - & - & - & - & - \\
\hline 2.5 dah & + & - & - & - & - & - & - & - \\
\hline 3 dah & + & + & + & + & + & - & - & - \\
\hline 4 dah & + & + & + & + & + & - & - & - \\
\hline 5 dah & + & + & + & + & + & + & + & + \\
\hline
\end{tabular}

Abbreviations and symbols: days after hatching (dah), presence (+), absence (-).

The pituitary could be distinguished from the hypothalamus at 2.5 dah being a round gland ventrally located in relation to the brain (Fig. 1C). At 3 dah, the pituitary gland presented an elongated shape, where the early segregation of the pituitary regions can be seen, i.e. the glandular portion, or adenohypophysis $(\mathrm{AH})$, and the nervous portion, or neurohypophysis (NH) (Fig. 1D). In parallel, we also detected the first 
appearance of $\mathrm{ACTH}, \mathrm{MSH}, \mathrm{TSH}$, and FSH-expressing cells. ACTH and MSH cells were immunostained by the same antibody, but the two groups of positive cells were seen in the anterior and posterior regions of the pituitary, respectively (Fig. 1E). On the other hand, in the central region of the pituitary gland, a reduced group cells were recognized, the TSH cells (Fig. 1F). The FSH cells, the first type of gonadotropic cell to appear during the larval period, were immunodetected in the border of the pituitary gland (Fig. 1G).

At 5 dah, an increase in the size of the gland was noted (Fig. $1 \mathrm{H}$ ). In addition, the three remaining $\mathrm{AH}$ cells, the SL, GH, and LH cells were detected at this phase. The SL cells were immunodetected in the posterior region of the pituitary gland (Fig. 1I), whereas few GH cells were detected in its central region (Fig. 1J). The LH cells (Fig. 1K) were round and more numerous than the first detected FSH cells. The LH cells were also distributed in the central region of the pituitary gland.

From 20 dah on, the specimens were considered as juveniles. At this time, the pituitary was located on the floor of the hypothalamus where the development of the stalk was seen (Fig. 2A). At this stage, the three AH lobes were distinguished - rostral pars distalis (RPD), proximal pars distalis (PPD) and pars intermedia $(\mathrm{PI})$ - as they displayed different staining properties when submitted to the Mallory trichrome technique (Fig. 2A). In addition, an increase in the area occupied by the $\mathrm{NH}$ was observed, as well as its ramification by the three $\mathrm{AH}$ lobes.

In this phase, a stronger immunostaining in PRL cells was noted (Fig. 2B). The ACTH and MSH cells were elongated with an eccentric nucleus, and ACTH cells presented a granular immunostaining (Fig. 2C). We found some elongated TSH cells in the PPD lobe, where these cells were isolated or grouped (Fig. 2D). Elongated FSH producing cells were found in the PPD and RPD lobes (Fig. 2E). The SL cells were round cells with a lighter immunostaining than when they were first detected and were seen on the periphery of PI lobe (Fig. 2F). The GH cells presented a strong labeling and were distributed throughout the PPD lobe (Fig. 2G). Finally, few LH cells were found in the PPD lobe (Fig. 2H).

Until 30 dah, the pituitary did not show marked changes in its size and shape. However, from then on, the pituitary development had a great increase in size, accompanied by an increase in each AH cell populations. At 60 dah and on (Fig. 3A), the pituitary gland showed a marked morphological change, acquiring an oval shape, similar to the morphology found in adult specimens of $A$. lacustris. The gland was bigger and connected to the hypothalamus by a short and thin stalk.

At the adult pituitary, the PRL cells were round cells with a large, central nucleus. A large population of PRL cells was found in the RPD lobe (Fig. 3B), especially in their border and close to blood vessels that were present in this region. On the other hand, ACTH cells were distributed between PRL cells, mostly around $\mathrm{NH}$ branches (Fig. $3 \mathrm{C}$ ). These cells were found elongated with an eccentric nucleus. MSH cells were morphologically similar to the ACTH cells and were abundant in the PI lobe distributed along the $\mathrm{NH}$ branches (Fig. 3C). A large population of elongated TSH cells were observed in all PPD lobe extension (Fig. 3D). FSH and LH cells were distributed in the PPD lobe. FSH cell were seen in all PPD lobe (Fig. 3E), while LH cells were less numerous and distributed in the ventral region of PPD lobe, and in its border with the PI lobe (Fig. $3 \mathrm{H})$. The SL cells were round cells with an eccentric nucleus located surrounding the 
blood vessels in the PI lobe (Fig. 3F). The GH cells maintained a strong labeling appearing in groups of rounded cells distributed throughout the PPD lobe (Fig. 3G).

The key aspects of pituitary gland development and the ontogeny of AH cell in A. lacustris are summarized in Figure 4.

\section{Discussion}

Once there are a few data related to the pituitary gland development in Neotropical fish species, this study provides a systematic and detailed description of the pituitary morphogenesis in the characid fish $A$. lacustris, since hatching until adult period, using histochemistry and immunohistochemistry methods.

In A. lacustris the prolactin cells (PRL) were detected with 1 dah. They were also found with up to 0.5 dah in Salminus brasiliensis (Jesus et al. 2014), with 2 dah in Cichlasoma dimerus (Pandolfi et al. 2001), and with 7 dah in Sparus aurata (Villaplana et al. 2000). In juveniles of Ctenopharyngodon idella, PRL cells were found in individuals with 51-69 mm (Grandi et al. 2014), and in zebrafish (Danio rerio) they were detected only 30 hours after fertilization (Herzog et al. 2003).

On the timing of the onset of adenohypophyseal cells, prolactin is typically the first cell type found in the secretory portion of the gland. This early onset is related to key stages, since the development of osmoregulatory functions is hormonally controlled by PRL (Varsamos et al. 2005), hence the importance of this hormone in the initial stages after hatching (Laiz-Carrión et al. 2003; Saga et al. 1999). In teleosts, PRL is also involved in larval growth, and embryos and larvae differentiation (Majumdar and Elsholtz 1994; Naito et al. 1993) and immunoregulation (Dorshkind and Horseman 2000). Thus, it seems that PRL is essential from the beginning of larval development in A. lacustris also.

In A. lacustris, ACTH-producing cells were detected at 3 dah, at the same time of larval development as MSH-producing cells. This synchrony was also observed in S. brasiliensis at 0.5 dah (Jesus et al. 2014), and $C$. dimerus at 1.5 dah (Pandolfi et al. 2001). The adrenocorticotropin (ACTH) and melanocortin (MSH) hormones are polypeptides that display homologous amino acid sequences, so, the first 13 amino acids of the ACTH sequence coincide with those of $\mathrm{MSH}$. In addition, these hormones present a common precursor, the proopiomelanocortin (POMC) (Kawauchi and Sower 2006).

The POMC family hormones can be detected at different times, having been detected even at the time of hatching in Plecoglossus altivelis (Saga et al. 1999). In species in which these hormones were detected after hatching, this always occurs in early stages of larval development. It is known that ACTH acts on the adrenal glands promoting the release of glucocorticoids and cortisol, which, in turn, participate in important physiological processes, such as stress response, metabolism adjustment and osmoregulation (Wendellar-Bonga 1997). On the other hand, MSH promotes the dispersion of melanin granules (Agulleiro et al. 2006). Thus, the presence of these hormones seems to be related to the adaptation of the newly hatched larvae to a new environment (Laiz-Carrión et al. 2003; Tsalafouta et al. 2017). 
The thyroid hormone (TSH)-producing cells were also detected at 3 dah. Few studies have described the chronology of the appearance of these cells. TSH cells were detected in Oncorhynchus keta prior to hatching (Naito et al. 1993), in S. aurata during hatching (García-Ayala et al. 2003), and in P. altivelis up to 50 dah (Saga et al. 1999). In the species in which it was not possible to detect TSH-producing cells, the main problems reported were associated to the reduced size of the pituitary gland in the larval stage (Laiz-Carrión et al. 2003), the absence of this hormone in the early stages of development or yet to the non-immunoreactivity of anti- human TSH in some fish species (Jesus et al. 2014).

TSH acts on the thyroid by regulating the synthesis of thyroxine (T4) and triiodothyronine (T3), which, in turn, regulate many physiological processes in fish (Peter 2011). TSH also acts during development, giving the body shape, head size, fin and skin growth, scales, blood tissue, and liver development (Power et al. 2001). All these functions punctuate the need for TSH during the early development.

This is the first study to use homologous antibodies to investigate the ontogeny of gonadotropic cells in a Neotropical fish species. The anti-A. lacustris Fsh and Lh beta subunits here used were developed and standardized previously by De Jesus et al. (2017). These homologous antibodies allowed us to avoid the several known problems related to the immunodetection of fish gonadotropins employing heterologous antibodies. In A. lacustris, FSH-producing cells were initially detected at 3 dah, followed by LH-producing cells at 5 dah. This fact corroborates the detection of the FSH cells prior to the detection of the LH cells in the existing ontogeny studies of the AH cells of other teleosts, such as $C$. dimerus [FSH - 21 dah and LH 60 dah] (Pandolfi et al. 2006), S. aurata [FSH - 22 dah and LH - 82 dah] (Power and Canário 1992), and D. rerio [FSH - 4 dah and LH - 25 dah] (Herzog et al. 2003).

The asynchrony in the appearance of FSH and LH cells in the different teleosts species reveals that these hormones are likely to be produced in distinct populations of AH cells, as occurs in $C$. dimerus (Pandolfi et al. 2006). In addition, at 20 dah in A. lacustris, the number of FSH cells was greater than the number of LH cells, which also corroborates with that assertion. The variation in the appearance and detection of these cells may still be related to the reproductive cycle, since the gonadotropic hormones produced by the pituitary gland act directly on the gonads and are still capable of controlling the production of sexual steroids (Agulleiro et al. 2006). The FSH and LH-producing cells in A. lacustris appeared before the beginning of sexual differentiation, as the gonadal differentiation occurs at 58 dah in females and at 72 dah in males, according to Adolfi et al. (2015). At 20 dah, a great synthesis activity of the gonadotropic hormones was observed in juveniles of $A$. lacustris. These results corroborate the findings in Odontesthes bonariensis (Miranda et al. 2001) that had FSH and LH cells detected with 28 dah and 21 dah, respectively, suggesting that these hormones are produced before the gonadal differentiation (Grandi et al. 2014).

In A. lacustris, somatolactin (SL) cells were detected at 5 dah. These cells are responsible for producing somatolactin, a hormone only described in fish so far (Kawauchi and Sower 2006). These cells were also detected in D. rerio at 30 dah (Herzog et al. 2003), in S. brasiliensis at 1.5 dah (Jesus et al. 2014), in $C$. dimerus at 2 dah (Pandolfi et al. 2001), and in S. aurata at 3 dah (Villaplana et al. 1997). Furthermore, SL 
may be present in two forms, $\alpha$-somatolactin and $\beta$-somatolactin, that may be produced by the same cell or by separate cells, as in the Carassius auratus pituitary, where the presence of polymorphism of SLproducing cells has been suggested (Azuma et al. 2012).

$S L$ is found in the initial stages of development because it participates in processes related to the adaptations of the organism, mainly in key stages for the proper development of the larvae. In this way, SL is involved in aspects of adaptation to the environment (Rand-Weaver et al. 1995; Zhu and Thomas 1998), as the adaptation to the background color of the environments (Cánepa et al. 2012) and to the pigmentation regulation in fish (Fukamachi et al. 2004). In the latter study, the authors demonstrated that the mutation of the SL gene produces alteration in the color of the animal, generating white individuals. The SL is also linked to the metabolism processes, participating in the metabolic regulation of calcium (Kaneko and Hirano 1993), immune function (Dorshkind and Horseman 2000), reproduction process (Mousa and Mousa 2000), lipid metabolism, and cortisol secretion (Fukamachi et al. 2005).

$\mathrm{GH}$-producing cells in A. lacustris were also detected at 5 dah. Immunostaining was initially observed in only a few cells. However, in the subsequent phases, the sections submitted to the anti-GH antibody presented intense immunostaining in almost the entire PPD lobe, and at 20 dah also in the PI lobe. GH was also detected at distinct times in different teleosts species. However, it was detected at the same stage of larval development as PRL-producing cells in C. dimerus (Pandolfi et al. 2001) and S. aurata (Villaplana et al. 2000). In addition, it has been reported in the literature that GH-producing cells were also found in PPD and PI lobes (Quesada et al. 1988), or even in RPD lobe (Laiz-Carrión et al. 2003; Power and Canário 1992; Segura-Noguera et al. 2000).

In teleosts, $\mathrm{GH}$ is the main hormone acting in the promotion of animal growth, being present in the first stages of development. This is a crucial hormone for larval development, as it plays a role in energy mobilization and osmoregulation (Björnsson et al. 2002). Recent functional studies in zebrafish, using knockouts for GH, PRL, and SL, indicated that these hormones play an important role in the development and growth of the swim bladder, head, body, eyes, and melanophores (Zhu et al. 2007). In A. lacustris (herein), H. hippoglossus (Einarsdóttir et al. 2006), S. brasiliensis (Jesus et al. 2014), and C. dimerus (Pandolfi et al. 2001) the SL-producing cells appeared simultaneously to the GH-producing ones. This may be related to the fact that these hormones belong to the same family, and the difference in the chronology of the appearance is probably due to the larval development being different among the fish species.

Finally, the pituitary gland of $A$. lacustris was detected shortly after hatching and presented some morphological changes throughout its development. The early detection of all $\mathrm{AH}$ cells during larval development suggests that these hormones actively participate in A. lacustris larval process. The ontogeny of $\mathrm{AH}$ cells in $\mathrm{A}$. lacustris corroborates the heterogeneity in the appearance of these cell types in teleosts. Most of the morphological features in the adult pituitary are similar to those described for other teleosts species. 


\section{Declarations}

Funding: This work was supported by the National Council for Scientific and Technological Development [CNPq and BCD-ICB/USP/ Social Demand] and the São Paulo Research Foundation (FAPESP) [grant number \#2014/23451-0].

Competing interest: The authors have no relevant financial or non-financial interests to disclose.

Ethics approval/declarations: All experimental procedures were performed according to the procedure approved by the Ethics Committee on Animal Experiments of the Institute of Biomedical Sciences (ICB) of the University of Sao Paulo (USP), \#53/2013.

Consent to participate (It is not applicable)

Consent for publication: All listed authors have approved the manuscript before submission and consented to the submission and publication of the manuscript in this journal.

Data availability (It is not applicable)

Code availability (It is not applicable)

Authors' Contributions: Giovana Souza Branco, Lázaro Wender O. De Jesus, Chayrra Chehade, Maria Ines Borella contributed to the study conception and design. Material preparation, data collection and analysis were performed by Giovana Souza Branco, Lázaro Wender O. De Jesus, Chayrra Chehade, Monica Cassel, and Marília de Paiva Camargo. The first draft of the manuscript was written by Giovana Souza Branco, Lázaro Wender O. De Jesus, and Monica Cassel, and all authors commented on previous versions of the manuscript. All authors read and approved the final manuscript.

Acknowledgments: The authors would like to thank Cruz Alberto Mendonza Rigonati for the technical support, Dr Patrícia Gama, for allowing the use Olympus light microscope, Dr Elizabeth Romagosa for the theoretical and technical explanations regarding this study, and Votorantim Energia Group (Company formerly called CESP - Paraibuna, São Paulo, Brazil) for the specimens' availability and a site for their collection. They are also thankful for the financial support received by the National Council for Scientific and Technological Development [CNPq and BCD-ICB/USP/ Social Demand] and the São Paulo Research Foundation (FAPESP) [grant number \#2014/23451-0].

\section{References}

1. Adamov NSM, Ferreira do Nascimento N, Maciel ECS, Pereira-Santos M, Senhorini JA, Calado LL, Evangelista MM, Nakaghi LSO, Guerrero AHM, Fujimoto T, Yasui GS (2017) Triploid induction in the yellowtail tetra, Astyanax altiparanae, using temperature shock: tools for conservation and aquaculture. J World Aquac Soc 48: 741-750. https://doi: 10.1111/jwas.12390 
2. Adolfi MC, Carreira, ACO, Jesus LWO, Bogerd J, Funes RM, Schartl M, Sogayar MC, Borella MI (2015) Molecular cloning and expression analysis of dmrt1 and sox9 during gonad development and male reproductive cycle in the lambari fish, Astyanax altiparanae. Reprod Biol Endocrinol 13:1-15. https://doi: 10.1186/1477-7827-13-2

3. Agulleiro B, García-Hernandez MP, García-Ayala A (2006) Teleost adenohypophysis: morphofunctional and development aspects. In: Reinecke M, Zaccone G, Kapoor BG (eds) Fish endocrinology, vol 1. Science Publishers, Enfield, pp 289-323

4. Azuma M, Suzuki T, Mochida H, Tanaka S, Uchiyama M, Takahashi A, Matsuda K (2012) Polymorphism of somatolactin-producing cells in the goldfish pituitary: immunohistochemical investigation for somatolactin $-\alpha$ and $-\beta$. Cell Tissue Res 350:167-176. https://doi: 10.1007/s00441012-1435-3

5. Björnsson BTH, Johansson V, Benedet S, Einarsdottir IE, Hildahl J, Agustsson T, Jonsson E (2002) Growth hormone endocrinology of salmonids: regulatory mechanisms and mode of action. Fish Physiol Biochem 27:227-242. https://doi: 10.1023/B:FISH.0000032728.91152.10

6. Brambila-Souza G, Mylonas CC, Mello PH, Kuradomi RY, Batlouni SR, Tolussi CE, Moreira RG (2019) Thermal manipulation and GnRHa therapy applied to the reproduction of lambari-do-rabo-amarelo, Astyanax altiparanae females (Characiformes: Characidae) during the non-breeding season. Gen Comp Endocrinol 279:120-128. https://doi: 10.1016/j.ygcen.2019.02.016

7. Branco GS, Melo AG, Ricci JMB, Digmayer M, Jesus LWO, Habibi HR, Nóbrega RH (2019) Effects of $\mathrm{GnRH}$ and the dual regulatory actions of $\mathrm{GnIH}$ in the pituitary explants and brain slices of Astyanax altiparanae males. Gen Comp Endocrinol 273:209-217. https://doi: 10.1016/j.ygcen.2018.08.006

8. Camargo MP, Cassel M, Jesus LWO, Nóbrega RH, Borella MI (2017) Characterization of undifferentiated spermatogonia and the spermatogonial niche in the lambari fish Astyanax altiparanae. Theriogenology 96:97-102. https://doi: 10.1016/j.theriogenology.2017.03.027

9. Cánepa MM, Zhu Y, Fossati M, Stiller JW, Vissio PG (2012) Cloning, phylogenetic analysis and expression of somatolactin and its receptor in Cichlasoma dimerus: Their role in long-term background color acclimation. Gen Comp Endocrinol 176:52-61. https://doi:

10.1016/j.ygcen.2011.12.023

10. Cassel M, Chehade C, Branco GS, Canepelle D, Romagosa E, Borella MI (2017) Ovarian development and the reproductive profile of Astyanax altiparanae (Teleostei, Characidae) over one year: Applications in fish farming. Theriogenology 98:1-15. https://doi:

10.1016/j.theriogenology.2017.04.044

11. Chehade C, Cassel M, Borella MI (2015) Induced reproduction in a migratory teleost species by water level drawdown. Neotrop Ichthyol 13:205-212. https:// doi: 10.1590/1982-0224-20140028

12. Cimbaluk GV, Ramsdorf WA, Perussolo MC, Santos HKF, Assis HCS, Schnitzler MC, Schnitzler DC, Carneiro PG, Cestari MM (2018) Evaluation of multiwalled carbon nanotubes toxicity in two fish species. Ecotoxicol Environ Saf 150:215-223. https://doi: 10.1016/j.ecoenv.2017.12.034 
13. Costa FG, Adolfi MC, Gomes CC, Jesus LWO, Batlouni SR, Borella MI (2014) Testes of Astyanax altiparanae: the Sertoli cell functions in a semicystic spermatogenesis. Micron 61:20-27. https://doi: 10.1016/j.micron.2014.02.004

14. De Jesus LWO, Bogerd J, Vieceli FM, Branco GS, Camargo MP, Cassel M, Moreira RG, Yan CYI, Borella MI (2017) Gonadotropin subunits of the characiform Astyanax altiparanae: Molecular characterization, spatiotemporal expression and their possible role on female reproductive dysfunction in captivity. Gen Comp Endocrinol 246:150-163. https://doi:

10.1016/j.ygcen.2016.12.004

15. Dorshkind K, Horseman ND (2000) The roles of prolactin, growth hormone, insulin-like growth factorI, and thyroid hormones in lymphocyte development and function: insights from genetic models of hormone and hormone receptor deficiency. Endocr Rev 21:292-312. doi: 10.1210/edrv.21.3.0397

16. Dos Santos MP, Yasui GS, Xavier PLP, Adamov NSM, Ferreira do Nascimento N, Fujimoto T, Senhorini JA, Nakaghi LSO (2016) Morphology of gametes, post-fertilization events and the effect of temperature on the embryonic development of Astyanax altiparanae (Teleostei, Characidae). Zygote 1:1-13. https://doi: 10.1017/S0967199416000101

17. Einarsdóttir IE, Silva N, Power DM, Smáradóttir H, Björnsson BT (2006) Thyroid and pituitary gland development from hatching through metamorphosis of a teleost flatfish, the Atlantic halibut. Anat Embryol 21:47-60. https://doi: 10.1007/s00429-005-0055-z

18. Ferreira do Nascimento N, Pereira-Santos M, Piva LH, Manzini B, Fujimoto T, Senhorini JA, Yasui GS, Nakaghi LSO (2017) Growth, fatty acid composition, and reproductive parameters of diploid and triploid yellowtail tetra Astyanax altiparanae. Aquaculture 471:163-171. https://doi:

10.1016/j.aquaculture.2017.01.007

19. Fukamachi S, Sugimoto M, Mitani H, Shima A (2004) Somatolactin selectively regulates proliferation and morphogenesis of neural-crest derived pigment cells in medaka. Proc Natl Acad Sci USA 101:10661-10666. https://doi: 10.1073/pnas.0401278101

20. Fukamachi S, Yada T, Mitani H (2005) Medaka receptors for somatolactin and growth hormone: phylogenetic paradox among fish growth hormone receptors. Genetics 171:1875-1883. https://doi: 10.1534/genetics. 105.048819

21. García-Ayala A, Villaplana M, García-Hernández MP, Chaves-Pozo E, Agulleiro B (2003) FSH-, LH-, and TSH-expressing cells during development of Sparus aurata L. (Teleostei) an immunocytochemical study. Gen Comp Endocrinol 134:72-79. https://doi: 10.1016/s0016-6480(03)00198-9

22. Grandi G, Marchetti MG, Lanzoni M, Chicca M (2014) Immunocytochemical and ultrastructural identification of adenohypophyseal cells in Ctenopharyngodon idella (Cypriniformes: Cyprinidae) during gonadal differentiation. Fish Physiol Biochem 40:1115-1139. https://doi: 10.1007/s10695014-9910-2

23. Herzog W, Zeng X, Lele Z, Sonntag C, Ting JW, Chang CY (2003) Adenohypophysis formation in the zebrafish and its dependence on Sonic Hedgehog. Dev Biol 254:36-49. https://doi: 10.1016/s00121606(02)00124-0 
24. Jesus LWO, Chehade C, Costa FG, Borella MI (2014) Pituitary gland morphogenesis and ontogeny of adenohypophyseal cells of Salminus brasiliensis (Teleostei, Characiformes). Fish Physiol Biochem 40:897-909. https://doi: 10.1007/s10695-013-9895-2

25. Kaneko T, Hirano T (1993) Role of prolactin and somatolactin in calcium regulation in fish. J Exp Biol 184:31-45. https://doi: 10.1242/jeb.184.1.31

26. Kawauchi H, Sower SA (2006) The dawn and evolution of hormones in the adenohypophysis. Gen Comp Endocrinol 148:3-14. https://doi: 10.1016/j.ygcen.2005.10.011

27. Kida BMS, Abdalla RP, Moreira RG (2016) Effects of acidic water, aluminum, and manganese on testicular steroidogenesis in Astyanax altiparanae. Fish Physiol Biochem 42:1347-1356. https://doi: 10.1007/s10695-016-0222-6

28. Laiz-Carrión R, Segura-Noguera MM, Martín del Río MP, Mancera JM (2003) Ontogeny of adenohypophyseal cells in the pituitary of the American shad (Alosa sapidissima). Gen Comp Endocrinol 132:454-464. https://doi: 10.1016/S0016-6480(03)00118-7

29. Majumdar S, Elsholtz HP (1994) Comparative aspects of pituitary development and Pit-1 function. In: Sherwood NM, Hew CL (eds) Fish physiology: Molecular endocrinology of fish, vol XIII. Academic Press, San Diego, pp 309-330

30. Miranda LA, Strüssmann CA, Somoza GM (2001) Immunocytochemical identification of GtH1 and $\mathrm{GtH} 2$ cells during the temperature-sensitive period for sex determination in pejerrey, Odontesthes bonariensis. Gen Comp Endocrinol 124:45-52. https://doi: 10.1006/gcen.2001.7687

31. Mousa MA, Mousa SA (2000) Implication of somatolactin in the regulation of sexual maturation and spawning of Mugil cephalus. J Exp Zool 287:62-73. https://doi: 10.1002/1097-010X

32. Naito N, Jesus EG, Nakai Y, Hirano T (1993) Ontogeny of pituitary cell-types and the hypothalamohypophysial relationship during early development of chum salmon, Oncorhynchus keta. Cell Tissue Res 272:429-437. https://doi: 10.1007/BF00318549

33. Nozaki M, Oshima Y, Miki M, Shimotani T, Kawauchi H, Sower SA (2005) Distribution of immunoreactive adenohypophysial cell types in the pituitaries of the Atlantic and the Pacific hagfish, Myxine glutinosa and Eptatretus burgeri. Gen Comp Endocrinol 143:142-150. https://doi: 10.1016/j.ygcen.2005.03.002

34. Pandolfi M, Cánepa MM, Ravaglia MA, Maggese MC, Paz DA, Vissio PG (2003) Melaninconcentrating hormone system in the brain and skin if the cichlid fish Cichlasoma dimerus: anatomical localization, ontogeny and distribution in comparison to a-melanocyte-stimulating hormone-expressing cells. Cell Tissue Res 311:61-69. https://doi: 10.1007/s00441-002-0654-4

35. Pandolfi M, Lo Nostro FL, Shimizu A, Pozzi AG, Meijide FJ, Vazquez GR (2006) Identification of immunoreactive FSH and LH cells in the cichlid fish Cichlasoma dimerus during the ontogeny and sexual differentiation. Anat Embryol 211:355-365. https://doi: 10.1007/s00429-006-0086-0

36. Pandolfi M, Paz DA, Maggese C, Ravaglia M, Vissio P (2001) Ontogeny of immunoreactive somatolactin, prolactin and growth hormone secretory cells in the developing pituitary gland of 
Cichlasoma dimerus (Teleostei, Perciformes). Anat Embryol 203:461-468. https://doi:

$10.1007 / \mathrm{s} 004290100172$

37. Peter MCS (2011) The role of thyroid hormones in stress response of fish. Gen Comp Endocrinol 172:198-210. https://doi: 10.1016/j.ygcen.2011.02.023

38. Power DM, Canário AV (1992) Immunocytochemistry of somatotrophs, gonadotrophs, prolactin and adrenocorticotropin cells in larval sea bream (Sparus aurata) pituitaries. Cell Tissue Res 269:341346. https://doi: 10.1007/BF00319626

39. Power DM, Llewellyn L, Faustino M, Nowell MA, Björnsson BT, Einarsdottir IE (2001) Thyroid hormones in growth and development of fish. Comp Biochem Physiol Part C 130:447-459. https://doi: 10.1016/S1532-0456(01)00271-X

40. Quesada J, Lozano MT, Ortega A, Agulleiro B (1988) Immunocytochemical and ultrastructural characterization of the cell types in the adenohypophysis of Sparus aurata L. (Teleost). Gen Comp Endocrinol 72:209-225. https://doi: 10.1016/0016-6480(88)90204-3

41. Rand-Weaver M, Pottinger TG, Sumpter JP (1995) Pronounced seasonal rhythms in plasma somatolactin levels in rainbow trout. J Endocrinol 146:113-119. https://doi: 10.1677/joe.0.1460113

42. Rodrigues MS, Siqueira-Silva DH, Quirino PP, Ninhaus-Silveira A, Veríssimo-Silveira R (2017) The efficiency of spermatogenesis and the support capacity of Sertoli cells in Characiformes. Theriogenology 103:149-152. https://doi: 10.1016/j.theriogenology.2017.07.025

43. Saga T, Yamaki KI, Doi Y, Yoshizuka Y (1999) Chronological study of the appearance of adenohypophysial cells in the ayu (Plecoglossus altivelis). Anat Embryol 200:469-475. https://doi: $10.1007 /$ s004290050295

44. Schreibman MP (1986) Pituitary Gland. In: Pang PKT, Schreibman MP (eds) Vertebrate endocrinology: Fundamentals and Biomedical Implications. Morphological Considerations, vol 1. Academic Press, Orlando, pp 11-55

45. Segura-Noguera MM, Laiz-Carrión R, Martín del Río MP, Mancera JM (2000) Immunocytochemical study of the pituitary gland of the white seabream (Diplodus sargus). Histochem J 32:733-742. https://doi: 10.1023/A:1004101127461

46. Tsalafouta A, Gorissen M, Pelgrim TNM, Papandroulakis N, Flik G, Pavlidis M (2017) a-MSH and melanocortin receptors at early ontogeny in European sea bass (Dicentrarchus labrax, L.). Sci Rep 7:46075. https://doi: 10.1038/srep46075

47. Varsamos S, Nebel C, Charmantier G (2005) Ontogeny of osmoregulation in postembryonic fish: A review. Comp Biochem Physiol Part A 141:401-429. https://doi: 10.1016/j.cbpb.2005.01.013

48. Villaplana M, García-Ayala A, Chaves-Pozo E, Agulleiro B (2000) Identification of mammosomatotropes, growth hormone cells and prolactin cells in the pituitary gland of the gilthead sea bream (Sparus aurata L., Teleostei) using light immunocytochemical methods: an ontogenetic study. Anat Embryol 202:421-429. https://doi: 10.1007/s004290000123

49. Villaplana M, García-Ayala A, García-Hernández MP, Agulleiro B (1997) Ontogeny of the immunoreactive somatolactin cells in the pituitary of gilthead sea bream (Sparus aurata L., 
Teleostei). Anat Embryol I196:227-234. https://doi: 10.1007/s004290000123

50. Wendellar-Bonga SE (1997) The stress response in fish. Physiol Rev 77:591-625. https://doi: 10.1152/physrev.1997.77.3.591

51. Yaron Z, Levavi-Sivan B (2011) Endocrine Regulation of Fish Reproduction. In: Farrell AP (ed) Encyclopedia of Fish Physiology: From Genome to Environment. Academic Press, San Diego, pp 1500-1508

52. Yasui GS, Senhorini JA, Shimoda E, Pereira-Santos M, Nakaghi LSO, Fujimoto T, Arias-Rodriguez L, Silva LA (2015) Improvement of gamete quality and its short-term storage: an approach for biotechnology in laboratory fish. Animal 9:464-470. https://doi: 10.1017/S1751731114002511

53. Zhu Y, Song D, Tran NT, Nguyen N (2007) The effects of the members of growth hormone family knockdown in zebrafish development. Gen Comp Endocrinol 150:395-404. https://doi: 10.1016/j.ygcen.2006.10.009

54. Zhu Y, Thomas P (1998) Effects of light on plasma somatolactin levels in red drum Sciaenops ocellatus. Gen Comp Endocrinol 111:76-82. https://doi: 10.1006/gcen.1998.7092

\section{Figures}

\section{Figure 1}

$<p>$ Development of the pituitary gland and immunodetection of the adenohypophyseal cells during the larval period of $<\mathrm{em}>\mathrm{A}$. lacustris $</ \mathrm{em}>$. ( $<$ strong $>\mathrm{A}</$ strong $>$ ) At 1 dah, the pituitary anlage was not detected, but ( $<$ strong $>B</$ strong $>$ ) a small group of cells was strongly immunostained by the anti-PRL antibody, the PRL cells, which are shown as small cells with a large, central nucleus ( $\mathrm{n}$ ).

( $<$ strong $>\mathrm{C}</$ strong $>$ and $<$ em $>$ inset $</$ em $>$ ) At 2.5 dah, the pituitary (dashed circle) could be distinguished from the hypothalamus. ( $<$ strong $>$ D $</$ strong $>$ and $<$ em $>$ inset $</$ em $>$ ) At 3 dah, the pituitary gland presented an elongated shape and it is divided in adenohypophysis (AH) and neurohypophysis (arrowhead). It was also detected the first appearance of (<strong $>\mathrm{E}</$ strong $>$ ) ACTH and MSH in the anterior and posterior regions of the pituitary, respectively, (<strong $>\mathrm{F}</$ strong $>$ ) TSH in the central region of the pituitary gland, and ( $<$ strong $>\mathrm{G}</$ strong $>$ ) FSH cells in the surroundings of the pituitary gland. ( $<$ strong $>\mathrm{H}</$ strong $>$ and $<$ em $>$ inset $</$ em $>$ ) At 5 dah, an increase in the size of the gland was noted. The (<strong $>\mathrm{l}</$ strong $>$ ) $\mathrm{SL}$, (<strong $>\mathrm{J}</$ strong $>$ ) $\mathrm{GH}$, and (<strong $>\mathrm{K}</$ strong $>$ ) LH cells were also detected at this phase, the first one in the posterior region and the other two in the central region of the pituitary gland. The rectangles in the figures indicate the areas shown in the $<$ em $>$ insets $</$ em $></ p>$

\section{Figure 2}


$<p>$ Pituitary gland in juveniles of $<\mathrm{em}>\mathrm{A}$. lacustris $</ \mathrm{em}>$ and the distribution of the adenohypophyseal cells. (<strong $>A</$ strong $>$ ) Pituitary is located on the floor of the hypothalamus presenting an adenohypophysis, which is divided in $<$ em>rostral pars distalis $</$ em $>$ (RPD), $<$ em>proximal pars distalis $</$ em $>(P P D)$ and <em $>$ pars intermedia $</ e m>(\mathrm{PI})$, a better-developed neurohypophysis $(\mathrm{NH})$, and the stalk. ( $<$ strong $>\mathrm{B}</$ strong $>$ and $<$ em $>$ inset $</$ em $>$ ) A stronger immunostaining in $P R L$ cells was noted at this phase. ( $<$ strong $>\mathrm{C}</$ strong $>$ and $<$ em $>$ inset $</$ em $>$ ) ACTH and MSH cells were elongated with an eccentric nucleus; ACTH cells presented a granular immunostaining. ( $<$ strong $>\mathrm{D}</$ strong $>$ and $<$ em>inset $</ e m>$ ) TSH cells were distributed singly or in groups in the PPD lobe. (<strong $>E</$ strong $>$ and $<$ em>inset</em>) Elongated FSH producing cells were found in the PPD and RPD lobes. ( $<$ strong $>\mathrm{F}</$ strong $>$ and $<$ em $>$ inset $</$ em $>$ ) Round, light stained SL cells were located on the periphery of PI lobe. ( $<$ strong $>\mathrm{G}</$ strong $>$ and $<$ em $>$ inset $</$ em $>$ ) $\mathrm{GH}$ were strong labeled and were distributed throughout the PPD lobe. ( $<$ strong $>\mathrm{H}</$ strong $>$ and $<$ em $>$ inset $</$ em $>$ ) Few LH cells were found in the PPD lobe. The squares in the figures indicate the areas shown in the $\left\langle\mathrm{em}>\right.$ insets $</ \mathrm{em}>$, and the $\left({ }^{*}\right)$ indicates the direction of the pituitary based on the RPD $</ p>$

\section{Figure 3}

$<p>$ Pituitary gland in adults of $<$ em $>A$. lacustris $</$ em $>$ and the final distribution of the adenohypophyseal cells. (<strong $>A</$ strong $>$ ) The pituitary gland presented an oval shape, with a new conformation of the $\mathrm{RPD}, \mathrm{PPD}$, and PI regions, and was connected to the hypothalamus by a short and thin stalk.

( $<$ strong $>\mathrm{B}</$ strong $>$ and $<$ em $>$ inset $</$ em $>$ ) Round PRL cells with central nucleus were found in the border of the RPD lobe and close to blood vessels. (<strong $>\mathrm{C}</$ strong $>$ and $<$ em $>$ inset $</$ em $>$ ) Elongated ACTH and MSH cells with an eccentric nucleus were distributed between PRL cells in the RPD lobe and in the PI lobe, respectively, both located mostly around $\mathrm{NH}$ branches. (<strong $>\mathrm{D}</$ strong $>$ and $<$ em $>$ inset $</$ em $>$ ) Elongated TSH cells were observed in all PPD lobe extension. ( $<$ strong $>E</$ strong $>$ and $<$ em $>$ inset $</$ em $>$ ) FSH cells, as well as TSH cells, were distributed in all PPD lobe extension. ( $<$ strong $>\mathrm{F}</$ strong $>$ and $<$ em>inset</em>) Round SL cells with an eccentric nucleus were located surrounding the blood vessels in the PI lobe. ( $<$ strong $>\mathrm{G}</$ strong $>$ and $<$ em $>$ inset $</$ em $>$ ) Rounded GH cells maintained a strong labeling and were distributed throughout the PPD lobe. ( $<$ strong $>\mathrm{H}</$ strong $>$ and $<$ em $>$ inset $</$ em $>$ ) LH cells were less numerous and were distributed in the ventral region of PPD lobe and in its border with the PI lobe. The squares in the figures indicate the areas shown in the insets. The squares in the figures indicate the areas shown in the $<\mathrm{em}>$ insets $</ \mathrm{em}>$, and the $\left({ }^{*}\right)$ indicates the direction of the pituitary based on the $\mathrm{RPD}</ \mathrm{p}>$

\section{Figure 4}

$<p>0$ verview of the key aspects of pituitary gland development and the ontogeny of $\mathrm{AH}$ cell in $<$ em>Astyanax lacustris $</ \mathrm{em}>$. It is possible to comparatively observe the growth of the pituitary and its 
conformational change, as well as the distribution and establishment of adenohypophyseal cells throughout this development $</ p>$ 